\title{
Histone Lysine Methylation and Neurodevelopmental Disorders
}

\author{
Jeong-Hoon Kim ${ }^{1,2,+}$, Jang Ho Lee ${ }^{3,+}+\mathbb{D}$, Im-Soon Lee ${ }^{3}$, Sung Bae Lee ${ }^{4, *}$ and \\ Kyoung Sang Cho ${ }^{3, *}$ \\ 1 Personalized Genomic Medicine Research Center, Korea Research Institute of Bioscience and \\ Biotechnology (KRIBB), Daejeon 34141, Korea; jhoonkim@kribb.re.kr \\ 2 Department of Functional Genomics, University of Science and Technology, Daejeon 34113, Korea \\ 3 Department of Biological Sciences, Konkuk University, Seoul 05029, Korea; \\ kingmega@konkuk.ac.kr (J.H.L.); islee@konkuk.ac.kr (I.-S.L.) \\ 4 Department of Brain \& Cognitive Sciences, DGIST, Daegu 42988, Korea \\ * Correspondence: sblee@dgist.ac.kr (S.B.L.); kscho@konkuk.ac.kr (K.S.C.); \\ Tel.: + 82-53-785-6122 (S.B.L.); +82-2-450-3424 (K.S.C.) \\ + These authors contributed equally to this work.
}

Received: 13 June 2017; Accepted: 27 June 2017; Published: 30 June 2017

\begin{abstract}
Methylation of several lysine residues of histones is a crucial mechanism for relatively long-term regulation of genomic activity. Recent molecular biological studies have demonstrated that the function of histone methylation is more diverse and complex than previously thought. Moreover, studies using newly available genomics techniques, such as exome sequencing, have identified an increasing number of histone lysine methylation-related genes as intellectual disability-associated genes, which highlights the importance of accurate control of histone methylation during neurogenesis. However, given the functional diversity and complexity of histone methylation within the cell, the study of the molecular basis of histone methylation-related neurodevelopmental disorders is currently still in its infancy. Here, we review the latest studies that revealed the pathological implications of alterations in histone methylation status in the context of various neurodevelopmental disorders and propose possible therapeutic application of epigenetic compounds regulating histone methylation status for the treatment of these diseases.
\end{abstract}

Keywords: epigenetic changes; histone lysine methylation; lysine methyltransferase; lysine demethylase; neurodevelopmental disorder

\section{Introduction}

Post-translational modifications of histone proteins in eukaryotic cells serve as crucial regulatory mechanisms of gene expression and are important for maintaining genomic integrity [1,2]. The histone modifications, such as its acetylation, methylation, phosphorylation, and ubiquitination, influence genomic activity by altering the binding force of DNA to histones or by acting as marks that recruit specific histone binding proteins [2]. Among these histone modifications, methylation has been implicated in heterochromatin formation and the regulation of promoter activity [3,4]. The histone residues, on which methylation occurs, include the following lysine and arginine residues: H3 (K4, 9, 27, 36, and 79), H4K20, H3 (R2, 8, 17, and 26), and H4R3 [5,6] (Figure 1a). These methylation sites are evolutionarily well conserved [7]. A variety of histone methyltransferases (writers), histone demethylases (erasers), and methylated histone binding proteins (readers) have been identified in various eukaryotic genomes [8]. Their site-specific molecular functions have been defined by biochemical and genetic studies $[2,8]$ (Table 1 ). 
Dysregulation of epigenetic modifications are associated with various human diseases, including neurodevelopmental disorders $[9,10]$. In particular, an increasing number of mutations in histone lysine methylation-related genes have been identified as intellectual disability-associated genes by exome sequencing with patients' samples [11-14] (Figure $1 \mathrm{~b}$ and Table 2). This highlights the importance of proper control of histone methylation during neurogenesis. In the current article, we provide an overview of the latest updates on the pathological implication of alterations in histone lysine methylation status in terms of neurodevelopmental disorders. Through this, we try to predict the future direction of research on this emerging field.

\section{(a)}

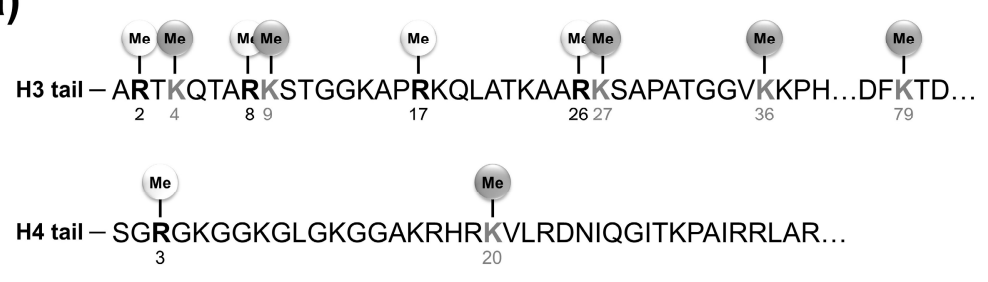

(b)

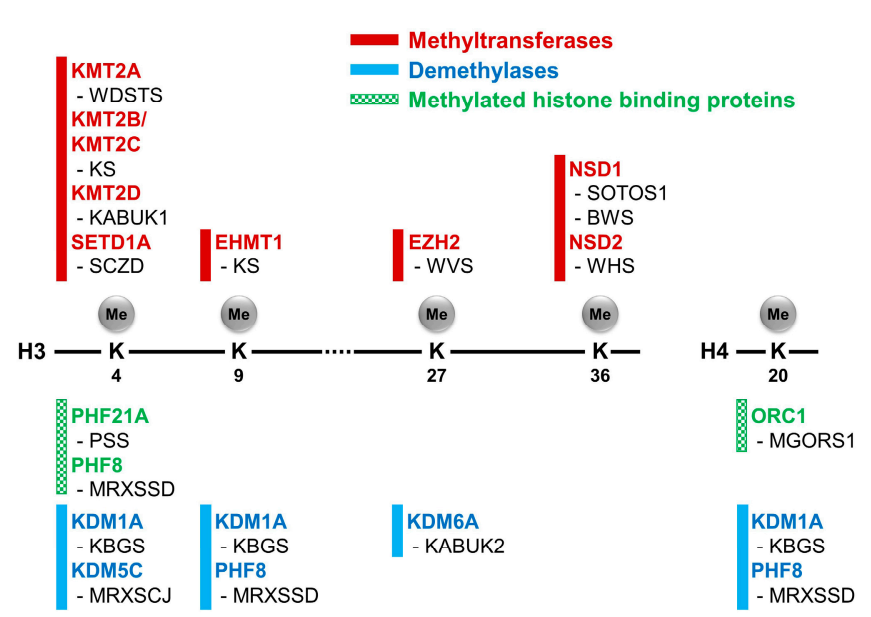

Figure 1. Histone methylation and neurodevelopmental disorders: (a) histone methylation sites in the tails of histone $\mathrm{H} 3$ and $\mathrm{H} 4$; and (b) histone methyltransferases, demethylases, and methylated histone binding proteins linked with neurodevelopmental disorders. Five methylation sites were associated with several neurodevelopmental disorders. BWS, Beckwith-Wiedemann syndrome; KABUK1/2, Kabuki syndrome 1/2; KBGS, KBG syndrome; KS, Kleefstra syndrome; MGORS1, Meier-Gorlin syndrome 1; MRXSCJ, Mental retardation, X-linked, syndromic, Claes-Jensen type; MRXSSD, Siderius X-linked mental retardation syndrome; PSS, Potocki-Shaffer syndrome; SCZD, Schizophrenia; SOTOS1, Sotos syndrome 1; WDSTS, Wiedemann-Steiner syndrome; WHS, Wolf-Hirshhorn syndrome; WVS, Weaver syndrome. 
Table 1. The names of the histone methylation-related factors mentioned in this paper and their synonyms.

\begin{tabular}{|c|c|c|c|c|}
\hline Symbol & Previous Symbol & Synonym(s) & Residue & Function \\
\hline ASH1L & ASH1L & ASH1, ASH1L1, huASH1, KMT2H & H3К36 & Methyltransferase \\
\hline DOT1L & DOT1L & DOT1, KIAA1814, KMT4 & H3K79 & Methyltransferase \\
\hline EHMT1 & EHMT1 & bA188C12.1, Eu-HMTase1, FLJ12879, KIAA1876, KMT1D & H3К9 & Methyltransferase \\
\hline EHMT2 & BAT8, C6orf30 & Em:AF134726.3, G9A, KMT1C, NG36/G9a & H3К9 & Methyltransferase \\
\hline EZH1 & EZH1 & KIAA0388, KMT6B & H3K27 & Methyltransferase \\
\hline EZH2 & EZH2 & ENX-1, EZH1, KMT6, KMT6A & H3K27 & Methyltransferase \\
\hline KDM1A & AOF2, KDM1 & BHC110, KIAA0601, LSD1 & H3К4, H3K9, H4K20 & Demethylase \\
\hline KDM2A & FBXL11, KDM2A & $\begin{array}{l}\text { CXXC8, DKFZP434M1735, FBL11, FBL7, FLJ00115, JHDM1A, } \\
\text { KIAA1004, LILINA }\end{array}$ & H3К36 & Demethylase \\
\hline KDM2B & FBXL10, KDM2B & CXXC2, Fbl10, JHDM1B, PCCX2 & H3К36 & Demethylase \\
\hline KDM3A & JMJD1, JMJD1A, KDM3A & JHMD2A, KIAA0742, TSGA & H3К9 & Demethylase \\
\hline KDM3B & C5orf7, JMJD1B, KDM3B & KIAA1082, NET22 & H3K9 & Demethylase \\
\hline KDM4A & JMJD2, JMJD2A, KDM4A & JHDM3A, KIAA0677, TDRD14A & H3K9, H3К36 & Demethylase \\
\hline KDM4B & JMJD2B, KDM4B & KIAA0876, TDRD14B & H3K9, H3К36 & Demethylase \\
\hline KDM4C & JMJD2C, KDM4C & GASC1, KIAA0780, TDRD14C & H3K9, H3К36 & Demethylase \\
\hline KDM5A & JARID1A, KDM5A, RBBP2 & - & H3K4 & Demethylase \\
\hline KDM5C & $\begin{array}{l}\text { JARID1C, KDM5C, MRX13, } \\
\text { SMCX }\end{array}$ & DXS1272E, XE169 & H3K4 & Demethylase \\
\hline KDM6A & KDM6A, UTX & - & H3K27 & Demethylase \\
\hline KDM6B & JMJD3, KDM6B & KIAA0346 & H3K27 & Demethylase \\
\hline KMT2A & KMT2A, MLL & ALL-1, CXXC7, HRX, HTRX1, MLL1A, TRX1 & H3K4 & Methyltransferase \\
\hline КМT2B & КМT2B & CXXC10, HRX2, KIAA0304, MLL1B, MLL2, MLL4, TRX2, WBP7 & Н3К 4 & Methyltransferase \\
\hline KMT2C & KMT2C, MLL3 & HALR, KIAA1506 & H3K4 & Methyltransferase \\
\hline KMT2D & KMT2D, MLL2, TNRC21 & ALR, CAGL114, MLL4 & H3K4 & Methyltransferase \\
\hline KMT5A & KMT5A, SETD8 & PR-Set7, SET07, SET8 & H4K20 & Methyltransferase \\
\hline КМТ5В & KMT5B, SUV420H1 & CGI-85 & $\mathrm{H} 4 \mathrm{~K} 20$ & Methyltransferase \\
\hline КМТ5С & KMT5C, SUV420H2 & MGC2705 & H4K20 & Methyltransferase \\
\hline NSD1 & STO & ARA267, FLJ22263, KMT3B & H3К36 & Methyltransferase \\
\hline NSD2 & WHSC1 & KMT3G, MMSET & H3K36 & Methyltransferase \\
\hline NSD3 & WHSC1L1 & FLJ20353, KMT3F, WHISTLE & H3К36 & Methyltransferase \\
\hline
\end{tabular}


Table 1. Cont

\begin{tabular}{|c|c|c|c|c|}
\hline Symbol & Previous Symbol & Synonym(s) & Residue & Function \\
\hline ORC1 & ORC1L & HSORC1, PARC1 & H4K20 & Recognition \\
\hline PHF2 & - & CENP-35, JHDM1E, KDM7C, KIAA0662 & H3K9, H4K20 & Demethylase \\
\hline PHF8 & - & JHDM1F, KDM7B, KIAA1111, ZNF422 & H3K9, H4K20/H3K4 & Demethylase/Recognition \\
\hline PHF21A & - & BHC 80, BM-006, KIAA1696 & $\mathrm{H} 3 \mathrm{~K} 4$ & Recognition \\
\hline RIOX1 & C14orf169 & FLJ21802, JMJD9, MAPJD, NO66 & H3К 4, H3К 36 & Demethylase \\
\hline SETD1A & - & KIAA0339, KMT2F, Set1 & H3K4 & Methyltransferase \\
\hline SETD1B & - & KIAA1076, KMT2G, Set1B & H3K4 & Methyltransferase \\
\hline SETD2 & - & FLJ23184, HIF-1, HYPB, KIAA1732, KMT3A & H3K36 & Methyltransferase \\
\hline SETD3 & C14orf154 & FLJ23027 & H3K4, H3K36 & Methyltransferase \\
\hline SETDB1 & SETDB1 & ESET, KG1T, KIAA0067, KMT1E, TDRD21 & H3K9 & Methyltransferase \\
\hline SETMAR & - & Mentase & H3K4, H3К36 & Methyltransferase \\
\hline SMYD2 & - & HSKM-B, KMT3C, ZMYND14 & H3K4, H3K36 & Methyltransferase \\
\hline SUV39H1 & SUV39H & KMT1A & H3K9 & Methyltransferase \\
\hline SUV39H2 & SUV39H2 & KMT1B FLJ23414 & Н3К9 & Methyltransferase \\
\hline UTY & UTY & KDM6AL, KDM6C & H3K27 & Demethylase \\
\hline \multicolumn{5}{|c|}{ The names of the proteins are followed by HUGO Gene Nomenclature Committee (http:/ / www.genenames.org/) } \\
\hline
\end{tabular}


Table 2. Neurodevelopmental disorders caused by mutations in histone methylation-related genes.

\begin{tabular}{|c|c|c|c|c|c|}
\hline Disorder & OMIM & Symptom & Gene & Residue & Function \\
\hline $\begin{array}{l}\text { Beckwith-Wiedemann } \\
\text { syndrome (BWS) }\end{array}$ & 130650 & $\begin{array}{c}\text { Pediatric overgrowth disorder involving a predisposition to tumor } \\
\text { development }\end{array}$ & NSD1 & H3К36 & Methyltransferase \\
\hline Kabuki syndrome 1 & 147920 & \multirow{2}{*}{$\begin{array}{l}\text { Congenital mental retardation, postnatal dwarfism, peculiar faces, broad } \\
\text { and depressed nasal tip, large prominent earlobes, cleft or high-arched } \\
\text { palate, scoliosis, short fifth finger, and persistence of finger pads }\end{array}$} & \multirow{2}{*}{$K M T 2 D K D M 6 A$} & \multirow{2}{*}{ Н3К4 Н3К27 } & \multirow{2}{*}{$\begin{array}{l}\text { Methyltransferase } \\
\text { Demethylase }\end{array}$} \\
\hline $\begin{array}{c}\text { Kabuki syndrome } 2 \\
\text { (KABUK1/2) }\end{array}$ & 300867 & & & & \\
\hline KBG syndrome (KBGS) & 148050 & $\begin{array}{l}\text { Macrodontia of the upper central incisors, distinctive craniofacial findings, } \\
\text { short stature, skeletal anomalies, neurologic involvement that includes } \\
\text { global developmental delay, seizures, and intellectual disability }\end{array}$ & KDM1A & Н3К4 Н3К9 Н4К20 & $\begin{array}{l}\text { Demethylase } \\
\text { Demethylase } \\
\text { Demethylase }\end{array}$ \\
\hline Kleefstra syndrome (KS) & 610253 & $\begin{array}{l}\text { Severe mental retardation, hypotonia, epileptic seizures, flat face with } \\
\text { hypertelorism, synophrys, anteverted nares, everted lower lip, carp mouth } \\
\text { with macroglossia, and heart defects }\end{array}$ & КМТ2В, КМТ2С ЕНМТ1 & Н3К4 Н3К4 Н3К9 & $\begin{array}{l}\text { Methyltransferase } \\
\text { Methyltransferase } \\
\text { Methyltransferase }\end{array}$ \\
\hline $\begin{array}{l}\text { Meier-Gorlin syndrome } 1 \\
\text { (MGORS1) }\end{array}$ & 224690 & $\begin{array}{l}\text { Severe intrauterine and postnatal growth retardation, microcephaly, bilateral } \\
\text { microtia, and aplasia or hypoplasia of the patellae }\end{array}$ & ORC1 & H4K20 & Recognition \\
\hline $\begin{array}{l}\text { Mental retardation, } \\
\text { X-linked, syndromic, } \\
\text { Claes-Jensen type } \\
\text { (MRXSCJ) }\end{array}$ & 300534 & $\begin{array}{l}\text { Severe mental retardation, slowly progressive spastic paraplegia, facial } \\
\text { hypotonia, and maxillary hypoplasia }\end{array}$ & KDM5C & H3K4 & Demethylase \\
\hline $\begin{array}{l}\text { Potocki-Shaffer syndrome } \\
\text { (PSS) }\end{array}$ & 601224 & $\begin{array}{l}\text { Craniofacial abnormalities, developmental delay, intellectual disability, } \\
\text { multiple exostoses, and biparietal foramina }\end{array}$ & PHF21A & H3K4 & Recognition \\
\hline Schizophrenia (SCZD) & 181500 & $\begin{array}{l}\text { Hallucinations and delusions, severely inappropriate emotional responses, } \\
\text { disordered thinking and concentration, erratic behavior, as well as social } \\
\text { and occupational deterioration }\end{array}$ & SETD1A & H3K4 & Methyltransferase \\
\hline $\begin{array}{l}\text { Siderius X-linked mental } \\
\text { retardation syndrome } \\
\text { (MRXSSD) }\end{array}$ & 300263 & $\begin{array}{l}\text { Mental retardation, a repaired cleft lip, a long face with broad nasal tip, long } \\
\text { hands with long thin fingers, and flat feet with long thin toes }\end{array}$ & PHF8 & Н3К4 Н3К9 Н4К20 & $\begin{array}{l}\text { Recognition } \\
\text { Demethylase } \\
\text { Demethylase }\end{array}$ \\
\hline $\begin{array}{l}\text { Sotos syndrome } 1 \\
\text { (SOTOS1) }\end{array}$ & 117550 & $\begin{array}{l}\text { Excessively rapid growth, acromegalic features, and non-progressive } \\
\text { cerebral disorder with mental retardation }\end{array}$ & NSD1 & Н3К36 & Methyltransferase \\
\hline Weaver syndrome (WVS) & 277590 & $\begin{array}{l}\text { Pre- and postnatal overgrowth, accelerated osseous maturation, } \\
\text { characteristic craniofacial appearance, and developmental delay, broad } \\
\text { forehead and face, ocular hypertelorism, prominent wide philtrum, } \\
\text { micrognathia, deep horizontal chin groove, and deep-set nails }\end{array}$ & EZH2 & H3К27 & Methyltransferase \\
\hline $\begin{array}{l}\text { Wiedemann-Steiner } \\
\text { syndrome (WDSTS) }\end{array}$ & 605130 & $\begin{array}{l}\text { Hypertrichosis cubiti associated with short stature, consistent facial features, } \\
\text { including long eyelashes, thick or arched eyebrows with a lateral flare, } \\
\text { down slanting and vertically narrow palpebral fissures, mild to moderate } \\
\text { intellectual disability, behavioral difficulties, and hypertrichosis on the back }\end{array}$ & KMT2A & H3K4 & Methyltransferase \\
\hline $\begin{array}{l}\text { Wolf-Hirschhorn } \\
\text { syndrome (WHS) }\end{array}$ & 194190 & $\begin{array}{l}\text { Pre- and postnatal growth deficiency, developmental disability of variable } \\
\text { degree, characteristic craniofacial features, and a seizure disorder }\end{array}$ & NSD2 & Н3К36 & Methyltransferase \\
\hline
\end{tabular}




\section{Histone Lysine Methylations and Related Factors}

In most cases, methylation of histone $\mathrm{H} 3$ lysine 4 (H3K4me) is primarily found at enhancers and promoters of actively transcribed genes, and the methylation status of genes (i.e., mono-, di-, tri-methylation) correlates with its transcriptional activity $[15,16]$. Members of the lysine methyl transferase 2 (KMT2) family catalyze the addition of methyl groups to H3K4 at the post-translational level, while lysine demethylases (KDMs) remove the methyl groups. This dynamically modulates chromatin structures $[17,18]$. The KMT2 family, which is highly conserved throughout eukaryotes, can be evolutionarily divided into three subgroups (i.e., KMT2A and KMT2B, KMT2C and KMT2D, and SETD1A and SETD1B) [4,19]. In addition, SMYD2 and SETD3 also have been identified as H3K4 methyltransferases, and eight KDMs are reported to target the H3K4me $[4,20]$.

Methylation of histone $\mathrm{H} 3$ lysine 9 (H3K9me) is associated with both heterochromatin formation and gene silencing in euchromatin [2]. H3K9me acts as a binding sit Counseling, e for HP1 [21,22] which forms a complex with chromatin-modifying factors crucial for heterochromatin formation when recruited to H3K9me $[23,24]$. In the euchromatic region, H3K9me contributes to HP1-mediated gene silencing [25]. H3K9me is catalyzed by several methyltransferases, such as EHMT1, EHMT2, SUV39H1, SUV39H2, SETDB1, dimeric EHMT1-EHMT2, and the PRDM family, and erased by the following lysine demethylases: KDM1, KDM3, KDM4, PHF2, and PHF8 $[8,26,27]$.

Histone H3 lysine 27 methylation (H3K27me) is a repressive chromatin mark that is involved in gene silencing during development and X-chromosome inactivation [28,29]. H3K27me is associated with the repression of developmental regulator genes in human and murine embryonic stem cells (ESCs) [30,31]. Intriguingly, a variety of promoters characteristically contain both H3K4me3 (an activating mark) and H3K27me (a repressive mark) in pluripotent ESCs, which is referred to as "bivalency." The change in the bivalent situation is associated with differentiation [32]. H3K27me, catalyzed by EZH1 or EZH2 containing Polycomb Repressive Complex (PRC) 2, is a binding site for PRC1 to compact chromosomes [33]. KDM6A, KDM6B, and UTY have been identified as erasers of H3K27me [8].

A role of methylation on histone $\mathrm{H} 3$ lysine 36 (H3K36me) has initially been reported in the activation of genes in various systems [34]. However, H3K36me also functions in various processes, including alternative splicing [35], dosage compensation [36], DNA damage response [37], and transcriptional repression [38], depending on the chromatin context. H3K36me is tightly regulated by multiple KMTs and KDMs [20]. In vitro and in vivo studies, to date, have demonstrated that there are the following eight types of KMTs regulating H3K36 methylation levels in humans: SETD2, SETD3, NSD1, NSD2, NSD3, ASH1L, SMYD2, and SETMAR [20]. Although all H3K36-specific methyltransferases contain highly conserved SET domains, the patterns of H3K36 methylation vary. Most H3K36 KMTs preferentially mono- and di-methylate the residue, whereas SETD2 is the only enzyme that catalyzes H3K36me3 and requires mono- or di-methylated H3K36 for its function [39]. Conversely, methylated H3K36 can be demethylated by six KDMs. The H3K36 KDMs, which all belong to the Jumonji protein family, contain the conserved JmjC domain consisting of the following three groups: JHDM1 (KDM2A, KDM2B), JHDM3 (KDM4A, KDM4B, KDM4C), and RIOX1 [40]. JHDM1 is specific for H3K36me1/me2 demethylation, whereas JHDM3 uses H3K36 and $\mathrm{H} 3 \mathrm{~K} 9$ residues as substrates for the me2/me3-specific demethylation [41]. Similarly, in addition to H3K36me2/me3-specific activity, RIOX1 preferentially demethylates H3K4me1/me3 residues [42].

Histone H3 lysine 79 methylation (H3K79me) is associated with a diverse range of cellular processes including telomeric silencing, cellular development, cell-cycle checkpoint, DNA repair, and transcription regulation [43]. However, only one H3K79-specific KMT is known, with no KDM for H3K79 demethylation reported to date. DOT1L is the sole enzyme that is responsible for all three forms of H3K79 methylation in humans [44]. In addition, DOT1L is unique because it is the only non-SET domain containing methyltransferase, which has been identified to date [18].

Methylation on Histone H4 lysine 20 (H4K20me) displays various biological processes depending on its methylated levels. H4K20me1 is associated with transcriptional activation, appearing in the most 
highly transcribed group of genes with other core modifications at active promoters [45]. H4K20me2 has distinct roles, such as marking points of replication origin and damage response in the DNA [46,47]. Conversely, H4K20me3 is associated with transcriptional repression at promoters and silencing of repetitive DNA and transposons $[45,48]$. H4K20me is catalyzed by three enzymes, with activities restricted to specific methylation states. KMT5A, the first identified H4K20 methyltransferase, is the only H4K20me1 enzyme [49]. H4K20me1 can be further di- and tri-methylated by KMT5B and KMT5C [50]. Similarly, several distinct demethylases are involved in the removal of specific H4K20me. PHF8 acts as a demethylase for H4K20me1 [51]. Intriguingly, as previously described, PHF8 is the KDM that has additional activities towards H3K9me1 and H3K9me2 [8]. In addition, LSD1n, an alternatively spliced form of KDM1A, demethylates H4K20me1 and H4K20me2 [52], while PHF2 displays demethylase activity on H4K20me3 [53].

\section{Neurodevelopmental Disorders Related with Histone Lysine Methylations}

\subsection{H3K4 Methylation}

\subsubsection{KMT2A and Wiedemann-Steiner Syndrome}

Mutations in KMT2A were reported to be associated with Wiedemann-Steiner syndrome (WDSTS; OMIM 605130), an extremely rare neurodevelopmental condition accompanied by microcephaly, short stature, autism-like phenotype, and aggression [54]. Interestingly, these abnormal brain functions were recapitulated in KMT2A heterozygous mutant mice, which displayed profound deficits in long-term contextual fear memory $[55,56]$. In particular, neuronal ablation of KMT2A in the postnatal forebrain and adult prefrontal cortex exhibited increased anxiety and robust cognitive deficits in mice. In the same study, the analyzing H3K4me3 level and the gene expression profiles in KMT2A-deficient cortical neurons revealed that the homeodomain transcription factor, MEIS2, was repressed in these mice. Moreover, MEIS2 knockdown in prefrontal cortex phenocopied memory defects elicited by the deletion of KMT2A [57], thus proposing a critical role of MEIS2 in the pathogenesis of WDSTS.

\subsubsection{KMT2D and Kabuki Syndrome 1}

The most well-studied neurodevelopmental disorder associated with dysregulated H3K4me is Kabuki syndrome 1 (KABUK1; OMIM 147920), which is a rare congenital syndrome characterized by a distinctive face (a reminiscent of the make-up of actors Kabuki, traditional Japanese music-drama) and mental retardation with additional features including autism, seizure, and microcephaly [58]. Heterozygous mutations in KMT2D were found in more than $50 \%$ of patients with KABUK1, with the majority of mutations resulting in the premature termination of the protein product. In addition, mutations in KDM6A, an H3K27me demethylase gene, were also reported to contribute to less than $10 \%$ of this syndrome, and this type is referred as Kabuki syndrome 2 (KABUK2; OMIM 300867) [59-62]. Recently, Bögershausen et al. identified two mutations in $R A P 1 A / B$, which encode the Ras family small GTPases, in patients with KABUK1 by whole exome sequencing [61]. The authors also demonstrated that mutant RAP1 morphant phenocopied KDM6A and KMT2D mutants in zebrafish, and that the MEK/ERK pathway signaling was perturbed in RAP1- and KMT2D-defective cells. Interestingly, these phenotypes were rescued by treatment with an MEK inhibitor. On the other hands, the reduction in neurogenesis and hippocampal memory defects exhibited in a KABUK1 mouse model were ameliorated by the treatment with a histone deacetylase (HDAC) inhibitor, AR-42 [63]. Furthermore, a ketogenic diet rescued hippocampal memory defects through the elevation of beta-hydroxybutyrate, an endogenous HDAC inhibitor, in the same mice model [64]. Taken together, these results potentially provide diverse therapeutic directions to treat, or at least mitigate, the symptoms of KABUK1. 


\subsubsection{SETD1A and Schizophrenia}

Extensive exome sequencing from over 200 patients with schizophrenia (SCZD; OMIM 181500) revealed two de novo mutations in SETD1A, which likely cause malfunction of SETD1A activity [65]. Furthermore, a strong association between the loss-of-function mutation of SETD1A and SCZD was confirmed by analyzing the whole exome sequencing of over 4000 patients with SCZD [66]. Interestingly, a recent bioinformatic analysis demonstrated that in addition to mutations in the protein coding region, mutations in the regulatory elements of SETD1A also contributed to the etiology of SCZD. De novo synonymous mutations within frontal cortex-derived DNase I-hypersensitive sites were enriched in SCZD, and SETD1A was identified as the highest statistical significant gene [67].

\subsubsection{H3K4me Demethylases and Neurodevelopmental Disorders}

Given the intimate association between H3K4 methylation and neurodevelopment disorders, it is rational to assume that KDMs that are responsible for demethylation of H3K4me can be also mutated in neurodevelopmental disorders. Indeed, homozygous missense mutation in KDM5A has been reported in an individual with intellectual disability [68]. Furthermore, KDM5C, another H3K4 demethylase coding gene, has been recurrently mutated in patients with mental retardation, $\mathrm{X}$-linked, syndromic, Claes-Jensen type (MRXSCJ; OMIM 300534) [68-70]. Intriguingly, KDM5C has been shown to be transcriptionally regulated by ARX, a homeobox transcription factor, which is frequently mutated in X-linked mental retardation and epilepsy [71-74]. Additionally, a missense mutation in amine oxidase domain of KDM1A has been reported in patients with mixed features of KABUK1 and KBG syndrome (KBGS; OMIM 148050), which are characterized by macrodontia, distinctive craniofacial findings, and intellectual disability [75]. It is noteworthy that KDM1A catalyzes the demethylation of mono- and di-methylated H3K4, while other KDMs can demethylate H3K4me1/2/3 [76].

\subsubsection{PHF21A and Potocki-Shaffer Syndrome}

Besides H3K4me writers and erasers, PHF21A, an unmethylated H3K4 reader, was associated with a neurodevelopmental disorder. PHF21A was translocated in patients with Potocki-Shaffer syndrome (PSS; OMIM 601224), characterized by multiple exostoses, parietal foramina, intellectual disability, and craniofacial anomalies [77-79]. This translocation commonly results in deletion of the PHD domain coding region of PHF21A, suggesting that dictation of unmethylated H3K4 is crucial for its functions. Accordingly, the deficiency of head development was observed in PHF21A morpholino-injected zebrafish, and this defect was rescued by injection of human PHF21A mRNA [78]. In addition, PHF21A, in combination with KDM1A, is a key component of the BHC complex, which is involved in the repression of neuron-specific genes [80]. Furthermore, $S C N 3 A$, a KDM1A target gene, was derepressed, and LSD1 occupancy at the SCN3A promoter was reduced in PHF21A-translocated lymphoblastoid cell lines [78], hence proposing the idea that interplay between KDM1A and PHF21A is indispensable for normal brain development.

\subsection{H3K9 Methylation}

\subsubsection{EHMT1 and Kleefstra Syndrome}

Mutations in EHMT1, a gene encoding H3K9 methyltransferase, have been associated with Kleefstra syndrome (KS; OMIM 610253) which is characterized by intellectual disability, childhood hypotonia, and distinctive facial features [81,82]. Previously, this syndrome was known as the $9 \mathrm{q}$ Subtelomeric Deletion syndrome, in which minimal critical deleted region comprises EHMT1 [83]. In agreement with the role of EHMT1 on neurodevelopment in human, both Drosophila EHMT mutants and EHMT1 heterozygous knockout mice showed deficits in dendrite branching, learning, and memory [84,85]. Recent studies revealed the functions of EHMT1 in neurons, which may explain the phenotypes of patients and animal models of KS. A study measuring network and single cell activity in cortical cultures showed that EHMT1 is important for cortical neuronal network 
development [86]. Additionally, EHMT1 mediates homeostatic synaptic scaling, which stabilizes the activity of neural networks by balancing excitation and inhibition [87]. Interestingly, recent studies using exome sequencing revealed that the KS phenotypic spectrum was also linked to mutations in KMT2B and KMT2C $[88,89]$, and these suggest that complicated epigenetic modules might underlie the pathogenesis of KS.

\subsubsection{PHF8 and Siderius X-Linked Mental Retardation Syndrome}

Siderius X-linked mental retardation syndrome (MRXSSD; OMIM 300263) is an X-linked intellectual disability condition; patients display mental retardation, a long face and broad nasal tip, and cleft lip and palate [90,91]. MRXSSD has been associated with mutations in PHF8 [91-93]. Interestingly, PHF8 has a histone lysine demethylase activity towards three different methylated lysines on histones, H3K9me1/2 and H4K20me1 [94-96], and also functions as a trimethylated H3K4 reader [94].

Loss of a PHF8 homolog in Caenorhabditis elegans resulted in axon guidance defects via the alteration of Hedgehog-like signaling [97]. Furthermore, injection of zebrafish PHF8 morpholino caused brain and craniofacial development defects [96], thus suggested a critical role of histone methylation dynamics regulated by PHF8 in MRXSSD. However, surprisingly, a recent study showed that Phf8-deficient mice had no obvious developmental defects and cognitive impairment, while Phf8-deficient primary cells had reduced the proliferative potential [98]. The results in mice indicated that MRXSSD is not simply caused by a single PFH8 mutation, but rather by its combination with other genetic or environmental factors at the same time. The different phenotypes exhibited by some animal models and varying degrees of intellectual disability of human patients with MRXSSD can be attributed to the various targets and complex functions of PHF8.

\subsection{H3K27 Methylation}

\section{EZH2 and Weaver Syndrome}

Weaver syndrome (WVS; OMIM 277590) is an autosomal dominant disorder characterized by overgrowth and intellectual disability [99-101]. Exome sequencing studies identified EZH2 as a causative gene of WVS [102,103]. EZH2 interacts with EED to form PRC2, which is an H3K27me3 methyltransferase complex [104]. Interestingly, mutations in EED were found in individuals displaying symptoms similar to those of WVS [14,105], suggesting that the dysregulation of H3K27 methylation is responsible for these symptoms.

Several studies have shown that EZH2 deficiencies in animal models induced abnormal neurogenesis in the cerebral cortex [106], cerebellum [107], and spinal cord [108] during embryonic development. Moreover, EZH2 is also implicated in adult hippocampal neurogenesis [109]. The alteration of neurogenesis induced by EZH2 deficiencies has been associated with various neurogenic processes, such as the reduction of neural progenitor cell proliferation [108-110], cell fate change [106,107,111-113], and neuronal migration [114-116]. These results suggest that EZH2-induced H3K27 methylation plays an important role in various processes of neurodevelopment, dysfunction of which might be closely related to intellectual disability in patients with WVS.

\subsection{H3K36 Methylation}

\subsubsection{NSD1 Defects in Sotos Syndrome 1 and Beckwith-Wiedemann Syndrome}

Recent studies demonstrated that disrupted levels or patterns of H3K36 methylation can cause a range of human diseases, including neurodevelopmental disorders. Among them, Sotos syndrome 1 (SOTOS1; OMIM 117550) represents an important human model system for studying the neurodevelopmental outcome of epigenetic dysregulation, which is caused by mutations in NSD1 [117]. SOTOS1 is an autosomal dominant disorder characterized by pre- and postnatal overgrowth, facial 
dysmorphism, macrocephaly, and non-progressive neurological delay [118]. Interestingly, amplified genomic events of NSD1 resulted in the opposite phenotypic outcome of SOTOS1, so that duplication in NSD1 led to reversed clinical phenotypes of SOTOS1 with microcephaly, as well as delayed bone age, indicating the importance of proper NSD1 expression during brain development [119]. In addition, it was shown that neuroblastoma and glioma may occur in human in the absence of NSD1 function [120]. Although the MAPK/ERK pathway was mapped as a downstream signaling pathway of NSD1-related overgrowth of stature in SOTOS1 [121], until recently, the molecular mechanisms how dysregulated NSD1 affects the mental retardation in SOTOS1 patients remains elusive. To date, two Sotos-like overgrowth syndromes called as Sotos syndrome 2 (SOTOS2; OMIM 614753) and 3 (SOTOS3; OMIM 617169) have been reported, which are caused by mutations in the NFIX and APC2 genes, respectively [122,123]. Among the products of the two genes, APC2, a WNT signaling pathway regulator, has recently been suggested as a crucial target of NSD1, of which defects may cause the intellectual disability associated with SOTOS [123]. In the mouse model system, Apc2 deficiency caused impaired learning and memory abilities along with an abnormal head shape. In addition, Nsd1 knockdown downregulated endogenous $A p c 2$ expression, and defective neuronal phenotypes caused by the knockdown were rescued by the forced expression of $A p c 2$, suggesting that APC2 may be a critical downstream gene of NSD1 in human neuronal cells.

Beckwith-Wiedemann syndrome (BWS; OMIM 130650) is another distinct overgrowth disorder with a broad clinical spectrum including hypoglycemia, ear creases/pits, cleft palate, and predisposition to embryonal tumors [124]. Martinez-y-Martinez et al. documented that mental retardation was observed in 6 of the 39 BWS cases [125]. It is well known that a major cause of BWS is the dysregulation of imprinted growth regulatory genes on chromosome 11p15 [126]. Interestingly, mutations in the NSD1 gene have been identified in 2 patients among 52 individuals clinically diagnosed with BWS, which suggests the involvement of NSD1 in imprinting of the 11p15 region [127].

\subsubsection{NSD2 and Wolf-Hirshhorn Syndrome}

NSD2 is one of the major genes associated with Wolf-Hirshhorn syndrome (WHS; OMIM 194190), of which key features include severe growth and mental retardation, microcephaly, "Greek helmet" facies, and closure defects [128]. Like patients with WHS, mice with Nsd2 gene deletions were growth-retarded, showed midline, craniofacial, and ocular anomalies [129]. However, these mice did not show any learning deficits [129]. Although the downstream effectors of NSD2, such as RUNX2 and p300, which are known to play a role in bone development [130], have been identified, the mechanism by which NSD2 deficiency causes neurological disorders in patients with WHS is still unknown.

\subsection{H4K20 Methylation}

Siderius X-Linked Syndromic Mental Retardation and Meier-Gorlin Syndrome 1

Thus far, two developmental diseases associated with dysregulated H4K20 methylation have been reported in human. As described above, one is MRXSSD (OMIM 300263) caused by mutations in PHF8, which encodes an eraser of H3K9 and H4K20 methylation. The other is Meier-Gorlin syndrome 1 (MGORS1; OMIM 224690) caused by homozygous or compound heterozygous mutation in the ORC1 gene [131], which encodes a specific reader of H4K20me2 [46]. MGORS1 is a rare disorder characterized by severe intrauterine, postnatal growth retardation, and microcephaly [132]. Interestingly, however, despite the presence of microcephaly, intellects of patients with MGORS1 are usually normal [133].

\section{Perspectives}

As reviewed above, the pathogenesis of various neurodevelopmental disorders is closely associated with alterations in histone methylation status, which, in many cases, can be primarily attributed to loss-of-function mutations in related factors. Given that histone methylation status 
is meticulously regulated by the balance between two opposing enzymes (i.e., KMTs and KDMs), pharmaceutical inhibition of specific targets counteracting the loss-of-function mutations responsible for diseases can be a possible therapeutic option. Interestingly, a subset of currently available psychotherapeutic drugs, such as the atypical antipsychotic Clozapine, the mood-stabilizer Valproate, and the antidepressant Phenelzine are known to interfere with histone methylation in the brain [134], although the relative contribution of this interference to their psychotherapeutic effects remains to be elucidated. In principle, an estimated 100 lysine and arginine residue-specific histone methyltransferases and demethylases [135] can be reasonable therapeutic targets, since they are considered more specific than HDACs [134]. Of note, histone methylation has been the most flourishing area of epigenetics research recently, and in line with this, huge efforts have been made to develop several potential therapeutic molecules, which specifically regulate histone methyltransferases and methylation reader proteins, particularly for cancer treatment [136]. For example, selective inhibitors, such as EPZ005687, GSK126, and EI1, which target EZH2 of PRC2, were recently reported by three independent groups to inhibit proliferation of B-cell lymphomas harboring EZH2-activating mutations [137-139]. In addition, tranylcypromine derivatives and polyaminoguanidine derivatives were designed and characterized to inhibit histone demethylases with potential anti-cancer activity [136]. Several epigenetic compounds, such as ORY-1001 and GSK2879552, are currently undergoing clinical trials for cancer treatment. If they meet the required biosafety standards, they could potentially be strong candidates for treating neurodevelopmental disorders, by correcting the impaired histone methylation status. Moreover, a microRNA-based gene silencing strategy targeting a specific histone methyltransferase or demethylase can be an alternative therapeutic option to consider in this regard. Indeed, several studies have reported the important roles of miRNA in histone methylation and following transcriptional gene silencing in various model systems [140-142]. Although further research is warranted, it will be interesting to establish whether these epigenetic compounds and/or microRNA-based specific gene silencing approaches have obvious therapeutic benefits for the patients with the neurodevelopmental disorders outlined in this review.

Acknowledgments: This work was supported by the DGIST R\&D and MIREBraiN program, Basic Science Research Program through the ministry of science, ICT \& future planning of Korea (17-BD-0402, 17-BT-02, and 17-01-HRSS-02); the Development of Platform Technology for Innovative Medical Measurements Program from the Korea Research Institute of Standards and Science (KRISS-2017-GP2017-0020) (Sung Bae Lee); the Basic Science Research Program of the National Research Foundation of Korea funded by the Ministry of Education, Science, and Technology (NRF-2014R1A1A2056768 and NRF-2017R1A2B4004241 Kyoung Sang Cho), and NRF-2014R1A1A3051462) (Im-Soon Lee); the Korea Health Technology Research \& Development Project, Ministry of Health \& Welfare, Republic of Korea (HI12C1472) (Kyoung Sang Cho); and KRIBB initiative program (Jeong-Hoon Kim).

Author Contributions: Sung Bae Lee and Kyoung Sang Cho designed the review; and Jeong-Hoon Kim, Jang Ho Lee, Im-Soon Lee, Sung Bae Lee and Kyoung Sang Cho wrote the manuscript.

Conflicts of Interest: The authors declare no conflict of interest.

\section{Abbreviations}

APC2
ARX
ASH1L
BHC complex
BWS
DOT1L
EED
EHMT1
EHMT2
ERK
ESC

Adenomatosis polyposis coli 2 Aristaless related homeobox ASH1 like histone lysine methyltransferase BRAF35/histone deacetylase complex Beckwith-Wiedemann syndrome DOT1 like histone lysine methyltransferase Embryonic ectoderm development Euchromatic histone lysine methyltransferase 1 Euchromatic histone lysine methyltransferase 2 Extracellular signal-regulated kinase Embryonic stem cells 
EZH1

EZH2

FAD

H3K4

H3K4me

H3K9

H3K9me

H3K27

H3K27me

H3K 36

H3K36me

H3K79

H3K79me

H3R2

H3R8

H3R17

H3R26

H4K20

H4K20me

H4R3

HDAC

HP1

JHDM

JmjC

KABUK1

KABUK2

KBGS

KS

LSD1n

KDM

KMT

MAPK

MEIS2

MEK

MGORS1

MRXSCJ

MRXSSD

NFIX

NSD1

NSD2

NSD3

ORC1

PHF2

PHF21A

PHF8

PRC1

PRC2

PRDM

PSS
Enhancer of zeste 1 polycomb repressive complex 2 subunit Enhancer of zeste 2 polycomb repressive complex 2 subunit Flavin adenosine dinucleotide

Histone H3 lysine 4

Methylation on histone $\mathrm{H} 3$ lysine 4

Histone H3 lysine 9

Methylation on histone H3 lysine 9

Histone H3 lysine 27

Methylation on histone $\mathrm{H} 3$ lysine 27

Histone H3 lysine 36

Methylation on histone $\mathrm{H} 3$ lysine 36

Histone H3 lysine 79

Methylation on histone H3 lysine 79

Histone $\mathrm{H} 3$ arginine 2

Histone $\mathrm{H} 3$ arginine 8

Histone $\mathrm{H} 3$ arginine 17

Histone $\mathrm{H} 3$ arginine 26

Histone H4 lysine 20

Methylation on histone $\mathrm{H} 4$ lysine 20

Histone $\mathrm{H} 4$ arginine 3

Histone deacetylase

Heterochromatin protein 1

JmjC-domain containing histone demethylases

Jumonji C

Kabuki syndrome 1

Kabuki syndrome 2

KBG syndrome

Kleefstra syndrome

Lysine-specific demethylase 1 variant

Lysine demethylase

Lysine methyl transferase

Mitogen-activated protein kinase

Myeloid ecotropic viral integration site 1 homolog 2

Mitogen-activated protein kinase kinase

Meier-Gorlin syndrome 1

Mental retardation, $\mathrm{X}$-linked, syndromic, Claes-Jensen type

Siderius $\mathrm{X}$-linked mental retardation syndrome

Nuclear factor I X

Nuclear receptor-binding SET domain protein 1

Nuclear receptor-binding SET domain protein 2

Nuclear receptor-binding SET domain protein 3

Origin recognition complex subunit 1

PHD finger protein 2

PHD finger protein 21A

PHD finger protein 8

Polycomb repressive complex 1

Polycomb repressive complex 2

PR/SET domain family

Potocki-Shaffer syndrome 


$\begin{array}{ll}\text { RAP1A/B } & \text { RAS-related protein 1A/B } \\ \text { RIOX1 } & \text { Ribosomal oxygenase 1 } \\ \text { RUNX2 } & \text { Runt related transcription factor 2 } \\ \text { SCZD } & \text { Schizophrenia } \\ \text { SCN3A } & \text { Sodium voltage-gated channel alpha subunit 3 } \\ \text { SETD1A } & \text { SET domain containing 1A } \\ \text { SETD1B } & \text { SET domain containing 1B } \\ \text { SETD2 } & \text { SET domain containing 2 } \\ \text { SETD3 } & \text { SET domain containing 3 } \\ \text { SETDB1 } & \text { SET domain bifurcated 1 } \\ \text { SETMAR } & \text { SET domain and mariner transposase fusion gene } \\ \text { SMYD2 } & \text { SET and MYND domain containing 2 } \\ \text { SOTOS1 } & \text { Sotos syndrome 1 } \\ \text { SOTOS2 } & \text { Sotos syndrome 2 } \\ \text { SOTOS3 } & \text { Sotos syndrome 3 } \\ \text { SUV39H1 } & \text { Suppressor of variegation 3-9 homolog 1 } \\ \text { SUV39H2 } & \text { Suppressor of variegation 3-9 homolog 2 } \\ \text { UTY } & \text { Ubiquitously transcribed tetratricopeptide repeat containing, Y-linked } \\ \text { WDSTS } & \text { Wiedemann-Steiner syndrome } \\ \text { WHS } & \text { Wolf-Hirshhorn syndrome } \\ \text { WVS } & \text { Weaver syndrome } \\ \end{array}$

\section{References}

1. Jenuwein, T.; Allis, C.D. Translating the histone code. Science 2001, 293, 1074-1080. [CrossRef] [PubMed]

2. Kouzarides, T. Chromatin modifications and their function. Cell 2007, 128, 693-705. [CrossRef] [PubMed]

3. Martin, C.; Zhang, Y. The diverse functions of histone lysine methylation. Nat. Rev. Mol. Cell Biol. 2005, 6, 838-849. [CrossRef] [PubMed]

4. Greer, E.L.; Shi, Y. Histone methylation: A dynamic mark in health, disease and inheritance. Nat. Rev. Genet. 2012, 13, 343-357. [CrossRef] [PubMed]

5. Berger, S.L. The complex language of chromatin regulation during transcription. Nature 2007, 447, 407-412. [CrossRef] [PubMed]

6. Di Lorenzo, A.; Bedford, M.T. Histone arginine methylation. FEBS Lett. 2011, 585, 2024-2031. [CrossRef] [PubMed]

7. Fuchs, J.; Demidov, D.; Houben, A.; Schubert, I. Chromosomal histone modification patterns-from conservation to diversity. Trends Plant Sci. 2006, 11, 199-208. [CrossRef] [PubMed]

8. Hyun, K.; Jeon, J.; Park, K.; Kim, J. Writing, erasing and reading histone lysine methylations. Exp. Mol. Med. 2017, 49, e324. [CrossRef] [PubMed]

9. Bale, T.L.; Baram, T.Z.; Brown, A.S.; Goldstein, J.M.; Insel, T.R.; McCarthy, M.M.; Nemeroff, C.B.; Reyes, T.M.; Simerly, R.B.; Susser, E.S. Early life programming and neurodevelopmental disorders. Biol. Psychiatry 2010, 68, 314-319. [CrossRef] [PubMed]

10. Millan, M.J. An epigenetic framework for neurodevelopmental disorders: From pathogenesis to potential therapy. Neuropharmacology 2013, 68, 2-82. [CrossRef] [PubMed]

11. Gilissen, C.; Hoischen, A.; Brunner, H.G.; Veltman, J.A. Unlocking Mendelian disease using exome sequencing. Genome Biol. 2011, 12, 228. [CrossRef] [PubMed]

12. Ronan, J.L.; Wu, W.; Crabtree, G.R. From neural development to cognition: Unexpected roles for chromatin. Nat. Rev. Genet. 2013, 14, 347-359. [CrossRef] [PubMed]

13. Vissers, L.E.; Gilissen, C.; Veltman, J.A. Genetic studies in intellectual disability and related disorders. Nat. Rev. Genet. 2016, 17, 9-18. [CrossRef] [PubMed]

14. Tatton-Brown, K.; Loveday, C.; Yost, S.; Clarke, M.; Ramsay, E.; Zachariou, A.; Elliott, A.; Wylie, H.; Ardissone, A.; Rittinger, O. Mutations in epigenetic regulation genes are a major cause of overgrowth with intellectual disability. Am. J. Hum. Genet. 2017, 100, 725-736. [CrossRef] [PubMed] 
15. Heintzman, N.D.; Stuart, R.K.; Hon, G.; Fu, Y.; Ching, C.W.; Hawkins, R.D.; Barrera, L.O.; Van Calcar, S.; $\mathrm{Qu}, \mathrm{C}$; Ching, K.A. Distinct and predictive chromatin signatures of transcriptional promoters and enhancers in the human genome. Nat. Genet. 2007, 39, 311-318. [CrossRef] [PubMed]

16. Heintzman, N.D.; Hon, G.C.; Hawkins, R.D.; Kheradpour, P.; Stark, A.; Harp, L.F.; Ye, Z.; Lee, L.K.; Stuart, R.K.; Ching, C.W. Histone modifications at human enhancers reflect global cell-type-specific gene expression. Nature 2009, 459, 108-112. [CrossRef] [PubMed]

17. Allis, C.D.; Berger, S.L.; Cote, J.; Dent, S.; Jenuwien, T.; Kouzarides, T.; Pillus, L.; Reinberg, D.; Shi, Y.; Shiekhattar, R. New nomenclature for chromatin-modifying enzymes. Cell 2007, 131, 633-636. [CrossRef] [PubMed]

18. Shilatifard, A. Chromatin modifications by methylation and ubiquitination: Implications in the regulation of gene expression. Annu. Rev. Biochem. 2006, 75, 243-269. [CrossRef] [PubMed]

19. Rao, R.C.; Dou, Y. Hijacked in cancer: The KMT2 (MLL) family of methyltransferases. Nat. Rev. Cancer 2015, 15, 334-346. [CrossRef] [PubMed]

20. Wagner, E.J.; Carpenter, P.B. Understanding the language of Lys36 methylation at histone H3. Nat. Rev. Mol. Cell Biol. 2012, 13, 115-126. [CrossRef] [PubMed]

21. Bannister, A.J.; Zegerman, P.; Partridge, J.F.; Miska, E.A.; Thomas, J.O.; Allshire, R.C.; Kouzarides, T. Selective recognition of methylated lysine 9 on histone H3 by the HP1 chromo domain. Nature 2001, 410, 120-124. [CrossRef] [PubMed]

22. Lachner, M.; O'carroll, D.; Rea, S.; Mechtler, K.; Jenuwein, T. Methylation of histone H3 lysine 9 creates a binding site for HP1 proteins. Nature 2001, 410, 116-120. [CrossRef] [PubMed]

23. Nakayama, J.-I.; Rice, J.C.; Strahl, B.D.; Allis, C.D.; Grewal, S.I. Role of histone H3 lysine 9 methylation in epigenetic control of heterochromatin assembly. Science 2001, 292, 110-113. [CrossRef] [PubMed]

24. Grewal, S.I.; Jia, S. Heterochromatin revisited. Nat. Rev. Genet. 2007, 8, 35-46. [CrossRef] [PubMed]

25. Schultz, D.C.; Ayyanathan, K.; Negorev, D.; Maul, G.G.; Rauscher, F.J. SETDB1: A novel KAP-1-associated histone $\mathrm{H} 3$, lysine 9-specific methyltransferase that contributes to HP1-mediated silencing of euchromatic genes by KRAB zinc-finger proteins. Genes Dev. 2002, 16, 919-932. [CrossRef] [PubMed]

26. Metzger, E.; Wissmann, M.; Yin, N.; Müller, J.M.; Schneider, R.; Peters, A.H.; Günther, T.; Buettner, R.; Schüle, R. LSD1 demethylates repressive histone marks to promote androgen-receptor-dependent transcription. Nature 2005, 437, 436-439. [CrossRef] [PubMed]

27. Kim, H.J.; Park, J.W.; Lee, K.H.; Yoon, H.; Shin, D.H.; Ju, U.I.; Seok, S.H.; Lim, S.H.; Lee, Z.H.; Kim, H.H. Plant homeodomain finger protein 2 promotes bone formation by demethylating and activating Run 2 for osteoblast differentiation. Cell Res. 2014, 24, 1231-1249. [CrossRef] [PubMed]

28. Plath, K.; Fang, J.; Mlynarczyk-Evans, S.K.; Cao, R.; Worringer, K.A.; Wang, H.; Cecile, C.; Otte, A.P.; Panning, B.; Zhang, Y. Role of histone H3 lysine 27 methylation in X inactivation. Science 2003, 300, 131-135. [CrossRef] [PubMed]

29. Wiles, E.T.; Selker, E.U. H3K27 methylation: A promiscuous repressive chromatin mark. Curr. Opin. Genet. Dev. 2017, 43, 31-37. [CrossRef] [PubMed]

30. Boyer, L.A.; Plath, K.; Zeitlinger, J.; Brambrink, T.; Medeiros, L.A.; Lee, T.I.; Levine, S.S.; Wernig, M.; Tajonar, A.; Ray, M.K. Polycomb complexes repress developmental regulators in murine embryonic stem cells. Nature 2006, 441, 349-353. [CrossRef] [PubMed]

31. Lee, T.I.; Jenner, R.G.; Boyer, L.A.; Guenther, M.G.; Levine, S.S.; Kumar, R.M.; Chevalier, B.; Johnstone, S.E.; Cole, M.F.; Isono, K.-I. Control of developmental regulators by Polycomb in human embryonic stem cells. Cell 2006, 125, 301-313. [CrossRef] [PubMed]

32. Harikumar, A.; Meshorer, E. Chromatin remodeling and bivalent histone modifications in embryonic stem cells. EMBO Rep. 2015, 16, 1609-1619. [CrossRef] [PubMed]

33. Margueron, R.; Reinberg, D. The Polycomb complex PRC2 and its mark in life. Nature 2011, 469, 343-349. [CrossRef] [PubMed]

34. Kizer, K.O.; Phatnani, H.P.; Shibata, Y.; Hall, H.; Greenleaf, A.L.; Strahl, B.D. A novel domain in Set2 mediates RNA polymerase II interaction and couples histone H3K36 methylation with transcript elongation. Mol. Cell. Biol. 2005, 25, 3305-3316. [CrossRef] [PubMed]

35. Kim, S.; Kim, H.; Fong, N.; Erickson, B.; Bentley, D.L. Pre-mRNA splicing is a determinant of histone H3K36 methylation. Proc. Natl. Acad. Sci. USA 2011, 108, 13564-13569. [CrossRef] [PubMed] 
36. Bell, O.; Conrad, T.; Kind, J.; Wirbelauer, C.; Akhtar, A.; Schübeler, D. Transcription-coupled methylation of histone $\mathrm{H} 3$ at lysine 36 regulates dosage compensation by enhancing recruitment of the MSL complex in Drosophila melanogaster. Mol. Cell. Biol. 2008, 28, 3401-3409. [CrossRef] [PubMed]

37. Fnu, S.; Williamson, E.A.; De Haro, L.P.; Brenneman, M.; Wray, J.; Shaheen, M.; Radhakrishnan, K.; Lee, S.-H.; Nickoloff, J.A.; Hromas, R. Methylation of histone H3 lysine 36 enhances DNA repair by nonhomologous end-joining. Proc. Natl. Acad. Sci. USA 2011, 108, 540-545. [CrossRef] [PubMed]

38. Strahl, B.D.; Grant, P.A.; Briggs, S.D.; Sun, Z.-W.; Bone, J.R.; Caldwell, J.A.; Mollah, S.; Cook, R.G.; Shabanowitz, J.; Hunt, D.F. Set2 is a nucleosomal histone H3-selective methyltransferase that mediates transcriptional repression. Mol. Cell. Biol. 2002, 22, 1298-1306. [CrossRef] [PubMed]

39. Edmunds, J.W.; Mahadevan, L.C.; Clayton, A.L. Dynamic histone H3 methylation during gene induction: HYPB/Setd2 mediates all H3K36 trimethylation. EMBO J. 2008, 27, 406-420. [CrossRef] [PubMed]

40. Cloos, P.A.; Christensen, J.; Agger, K.; Helin, K. Erasing the methyl mark: Histone demethylases at the center of cellular differentiation and disease. Genes Dev. 2008, 22, 1115-1140. [CrossRef] [PubMed]

41. Li, G.-M. Decoding the histone code: Role of H3K36me3 in mismatch repair and implications for cancer susceptibility and therapy. Cancer Res. 2013, 73, 6379-6383. [CrossRef] [PubMed]

42. Sinha, K.M.; Yasuda, H.; Coombes, M.M.; Dent, S.Y.; De Crombrugghe, B. Regulation of the osteoblast-specific transcription factor Osterix by NO66, a Jumonji family histone demethylase. EMBO J. 2010, 29, 68-79. [CrossRef] [PubMed]

43. Farooq, Z.; Banday, S.; Pandita, T.K.; Altaf, M. The many faces of histone H3K79 methylation. Mutat. Res. Rev. Mutat. Res. 2016, 768, 46-52. [CrossRef] [PubMed]

44. Van Leeuwen, F.; Gafken, P.R.; Gottschling, D.E. Dot1p modulates silencing in yeast by methylation of the nucleosome core. Cell 2002, 109, 745-756. [CrossRef]

45. Wang, Z.; Zang, C.; Rosenfeld, J.A.; Schones, D.E.; Barski, A.; Cuddapah, S.; Cui, K.; Roh, T.-Y.; Peng, W.; Zhang, M.Q. Combinatorial patterns of histone acetylations and methylations in the human genome. Nat. Genet. 2008, 40, 897-903. [CrossRef] [PubMed]

46. Kuo, A.J.; Song, J.; Cheung, P.; Ishibe-Murakami, S.; Yamazoe, S.; Chen, J.K.; Patel, D.J.; Gozani, O. The BAH domain of ORC1 links H4K20me2 to DNA replication licensing and Meier-Gorlin syndrome. Nature 2012, 484, 115-119. [CrossRef] [PubMed]

47. Botuyan, M.V.; Lee, J.; Ward, I.M.; Kim, J.-E.; Thompson, J.R.; Chen, J.; Mer, G. Structural basis for the methylation state-specific recognition of histone H4K20 by 53BP1 and Crb2 in DNA repair. Cell 2006, 127, 1361-1373. [CrossRef] [PubMed]

48. Jørgensen, S.; Schotta, G.; Sørensen, C.S. Histone H4 lysine 20 methylation: Key player in epigenetic regulation of genomic integrity. Nucleic Acids Res. 2013, 41, 2797-2806. [CrossRef] [PubMed]

49. Nishioka, K.; Rice, J.C.; Sarma, K.; Erdjument-Bromage, H.; Werner, J.; Wang, Y.; Chuikov, S.; Valenzuela, P.; Tempst, P.; Steward, R. PR-Set7 is a nucleosome-specific methyltransferase that modifies lysine 20 of histone $\mathrm{H} 4$ and is associated with silent chromatin. Mol. Cell 2002, 9, 1201-1213. [CrossRef]

50. Yang, H.; Pesavento, J.J.; Starnes, T.W.; Cryderman, D.E.; Wallrath, L.L.; Kelleher, N.L.; Mizzen, C.A. Preferential dimethylation of histone H4 lysine 20 by Suv4-20. J. Biol. Chem. 2008, 283, 12085-12092. [CrossRef] [PubMed]

51. Liu, W.; Tanasa, B.; Tyurina, O.V.; Zhou, T.Y.; Gassmann, R.; Liu, W.T.; Ohgi, K.A.; Benner, C.; Garcia-Bassets, I.; Aggarwal, A.K. PHF8 mediates histone H4 lysine 20 demethylation events involved in cell cycle progression. Nature 2010, 466, 508-512. [CrossRef] [PubMed]

52. Wang, J.; Telese, F.; Tan, Y.; Li, W.; Jin, C.; He, X.; Basnet, H.; Ma, Q.; Merkurjev, D.; Zhu, X. LSD1n is an H4K20 demethylase regulating memory formation via transcriptional elongation control. Nat. Neurosci. 2015, 18, 1256-1264. [CrossRef] [PubMed]

53. Stender, J.D.; Pascual, G.; Liu, W.; Kaikkonen, M.U.; Do, K.; Spann, N.J.; Boutros, M.; Perrimon, N.; Rosenfeld, M.G.; Glass, C.K. Control of proinflammatory gene programs by regulated trimethylation and demethylation of histone H4K20. Mol. Cell 2012, 48, 28-38. [CrossRef] [PubMed]

54. Strom, S.P.; Lozano, R.; Lee, H.; Dorrani, N.; Mann, J.; O’Lague, P.F.; Mans, N.; Deignan, J.L.; Vilain, E.; Nelson, S.F. De Novo variants in the KMT2A (MLL) gene causing atypical Wiedemann-Steiner syndrome in two unrelated individuals identified by clinical exome sequencing. BMC Med. Genet. 2014, 15, 49. [CrossRef] [PubMed] 
55. Gupta, S.; Kim, S.Y.; Artis, S.; Molfese, D.L.; Schumacher, A.; Sweatt, J.D.; Paylor, R.E.; Lubin, F.D. Histone methylation regulates memory formation. J. Neurosci. 2010, 30, 3589-3599. [CrossRef] [PubMed]

56. Kim, S.Y.; Levenson, J.M.; Korsmeyer, S.; Sweatt, J.D.; Schumacher, A. Developmental regulation of Eed complex composition governs a switch in global histone modification in brain. J. Biol. Chem. 2007, 282, 9962-9972. [CrossRef] [PubMed]

57. Jakovcevski, M.; Ruan, H.; Shen, E.Y.; Dincer, A.; Javidfar, B.; Ma, Q.; Peter, C.J.; Cheung, I.; Mitchell, A.C.; Jiang, Y. Neuronal Kmt2a/Mll1 histone methyltransferase is essential for prefrontal synaptic plasticity and working memory. J. Neurosci. 2015, 35, 5097-5108. [CrossRef] [PubMed]

58. Niikawa, N.; Matsuura, N.; Fukushima, Y.; Ohsawa, T.; Kajii, T. Kabuki make-up syndrome: A syndrome of mental retardation, unusual facies, large and protruding ears, and postnatal growth deficiency. J. Pediatr. 1981, 99, 565-569. [CrossRef]

59. Ng, S.B.; Bigham, A.W.; Buckingham, K.J.; Hannibal, M.C.; McMillin, M.J.; Gildersleeve, H.I.; Beck, A.E.; Tabor, H.K.; Cooper, G.M.; Mefford, H.C. Exome sequencing identifies MLL2 mutations as a cause of Kabuki syndrome. Nat. Genet. 2010, 42, 790-793. [CrossRef] [PubMed]

60. Paulussen, A.D.; Stegmann, A.; Blok, M.J.; Tserpelis, D.; Posma-Velter, C.; Detisch, Y.; Smeets, E.E.; Wagemans, A.; Schrander, J.J.; van den Boogaard, M.J.H. MLL2 mutation spectrum in 45 patients with Kabuki syndrome. Hum. Mutat. 2011, 32, E2018-E2025. [CrossRef] [PubMed]

61. Bögershausen, N.; Wollnik, B. Unmasking Kabuki syndrome. Clin. Genet. 2013, 83, 201-211. [CrossRef] [PubMed]

62. Lederer, D.; Grisart, B.; Digilio, M.C.; Benoit, V.; Crespin, M.; Ghariani, S.C.; Maystadt, I.; Dallapiccola, B.; Verellen-Dumoulin, C. Deletion of KDM6A, a histone demethylase interacting with MLL2, in three patients with Kabuki syndrome. Am. J. Hum. Genet. 2012, 90, 119-124. [CrossRef] [PubMed]

63. Benjamin, J.S.; Pilarowski, G.O.; Carosso, G.A.; Zhang, L.; Huso, D.L.; Goff, L.A.; Vernon, H.J.; Hansen, K.D.; Bjornsson, H.T. A ketogenic diet rescues hippocampal memory defects in a mouse model of Kabuki syndrome. Proc. Natl. Acad. Sci. USA 2017, 114, 125-130. [CrossRef] [PubMed]

64. Bjornsson, H.T.; Benjamin, J.S.; Zhang, L.; Weissman, J.; Gerber, E.E.; Chen, Y.-C.; Vaurio, R.G.; Potter, M.C.; Hansen, K.D.; Dietz, H.C. Histone deacetylase inhibition rescues structural and functional brain deficits in a mouse model of Kabuki syndrome. Sci. Transl. Med. 2014, 6, 256ra135. [CrossRef] [PubMed]

65. Takata, A.; Xu, B.; Ionita-Laza, I.; Roos, J.L.; Gogos, J.A.; Karayiorgou, M. Loss-of-function variants in schizophrenia risk and SETD1A as a candidate susceptibility gene. Neuron 2014, 82, 773-780. [CrossRef] [PubMed]

66. Singh, T.; Kurki, M.I.; Curtis, D.; Purcell, S.M.; Crooks, L.; McRae, J.; Suvisaari, J.; Chheda, H.; Blackwood, D.; Breen, G. Rare loss-of-function variants in SETD1A are associated with schizophrenia and developmental disorders. Nat. Neurosci. 2016, 19, 571-577. [CrossRef] [PubMed]

67. Takata, A.; Ionita-Laza, I.; Gogos, J.A.; Xu, B.; Karayiorgou, M. De novo synonymous mutations in regulatory elements contribute to the genetic etiology of autism and schizophrenia. Neuron 2016, 89, 940-947. [CrossRef] [PubMed]

68. Najmabadi, H.; Hu, H.; Garshasbi, M.; Zemojtel, T.; Abedini, S.S.; Chen, W.; Hosseini, M.; Behjati, F.; Haas, S.; Jamali, P. Deep sequencing reveals 50 novel genes for recessive cognitive disorders. Nature 2011, 478, 57-63. [CrossRef] [PubMed]

69. Jensen, L.R.; Amende, M.; Gurok, U.; Moser, B.; Gimmel, V.; Tzschach, A.; Janecke, A.R.; Tariverdian, G.; Chelly, J.; Fryns, J.-P. Mutations in the JARID1C gene, which is involved in transcriptional regulation and chromatin remodeling, cause X-linked mental retardation. Am. J. Hum. Genet. 2005, 76, 227-236. [CrossRef] [PubMed]

70. Tahiliani, M.; Mei, P.; Fang, R.; Leonor, T.; Rutenberg, M.; Shimizu, F.; Li, J.; Rao, A.; Shi, Y. The histone H3K4 demethylase SMCX links REST target genes to X-linked mental retardation. Nature 2007, 447, 601-605. [CrossRef] [PubMed]

71. Poeta, L.; Fusco, F.; Drongitis, D.; Shoubridge, C.; Manganelli, G.; Filosa, S.; Paciolla, M.; Courtney, M.; Collombat, P.; Lioi, M.B. A regulatory path associated with X-linked intellectual disability and epilepsy links KDM5C to the polyalanine expansions in ARX. Am. J. Hum. Genet. 2013, 92, 114-125. [CrossRef] [PubMed]

72. Strømme, P.; Mangelsdorf, M.E.; Scheffer, I.E.; Gécz, J. Infantile spasms, dystonia, and other X-linked phenotypes caused by mutations in Aristaless related homeobox gene, ARX. Brain Dev. 2002, 24, 266-268. [CrossRef] 
73. Kitamura, K.; Yanazawa, M.; Sugiyama, N.; Miura, H.; Iizuka-Kogo, A.; Kusaka, M.; Omichi, K.; Suzuki, R.; Kato-Fukui, Y.; Kamiirisa, K. Mutation of ARX causes abnormal development of forebrain and testes in mice and X-linked lissencephaly with abnormal genitalia in humans. Nat. Genet. 2002, 32, 359-369. [CrossRef] [PubMed]

74. Kato, M.; Das, S.; Petras, K.; Kitamura, K.; Morohashi, K.I.; Abuelo, D.N.; Barr, M.; Bonneau, D.; Brady, A.F.; Carpenter, N.J. Mutations of $A R X$ are associated with striking pleiotropy and consistent genotype-phenotype correlation. Hum. Mutat. 2004, 23, 147-159. [CrossRef] [PubMed]

75. Tunovic, S.; Barkovich, J.; Sherr, E.H.; Slavotinek, A.M. De novo ANKRD11 and KDM1A gene mutations in a male with features of KBG syndrome and Kabuki syndrome. Am. J. Med. Genet. 2014, 164, 1744-1749. [CrossRef] [PubMed]

76. Shi, Y. Histone lysine demethylases: Emerging roles in development, physiology and disease. Nat. Rev. Genet. 2007, 8, 829-833. [CrossRef] [PubMed]

77. Lan, F.; Collins, R.E.; De Cegli, R.; Alpatov, R.; Horton, J.R.; Shi, X.; Gozani, O.; Cheng, X.; Shi, Y. Recognition of unmethylated histone H3 lysine 4 links BHC80 to LSD1-mediated gene repression. Nature 2007, 448, 718-722. [CrossRef] [PubMed]

78. Kim, H.-G.; Kim, H.-T.; Leach, N.T.; Lan, F.; Ullmann, R.; Silahtaroglu, A.; Kurth, I.; Nowka, A.; Seong, I.S.; Shen, Y. Translocations disrupting PHF21A in the Potocki-Shaffer-syndrome region are associated with intellectual disability and craniofacial anomalies. Am. J. Hum. Genet. 2012, 91, 56-72. [CrossRef] [PubMed]

79. Labonne, J.D.; Vogt, J.; Reali, L.; Kong, I.K.; Layman, L.C.; Kim, H.G. A microdeletion encompassing PHF21A in an individual with global developmental delay and craniofacial anomalies. Am. J. Med. Genet. 2015, 167, 3011-3018. [CrossRef] [PubMed]

80. Hakimi, M.-A.; Bochar, D.A.; Chenoweth, J.; Lane, W.S.; Mandel, G.; Shiekhattar, R. A core-BRAF35 complex containing histone deacetylase mediates repression of neuronal-specific genes. Proc. Natl. Acad. Sci. USA 2002, 99, 7420-7425. [CrossRef] [PubMed]

81. Kleefstra, T.; Smidt, M.; Banning, M.; Oudakker, A.; Van Esch, H.; De Brouwer, A.; Nillesen, W.; Sistermans, E.; Hamel, B.; De Bruijn, D. Disruption of the gene Euchromatin Histone Methyl Transferase1 (Eu-HMTase1) is associated with the 9q34 subtelomeric deletion syndrome. J. Med. Genet. 2005, 42, 299-306. [CrossRef] [PubMed]

82. Kleefstra, T.; Brunner, H.G.; Amiel, J.; Oudakker, A.R.; Nillesen, W.M.; Magee, A.; Geneviève, D.; Cormier-Daire, V.; Van Esch, H.; Fryns, J.-P. Loss-of-function mutations in euchromatin histone methyl transferase 1 (EHMT1) cause the 9q34 subtelomeric deletion syndrome. Am. J. Hum. Genet. 2006, 79, 370-377. [CrossRef] [PubMed]

83. Harada, N.; Visser, R.; Dawson, A.; Fukamachi, M.; Iwakoshi, M.; Okamoto, N.; Kishino, T.; Niikawa, N.; Matsumoto, N. A 1-Mb critical region in six patients with 9q34. 3 terminal deletion syndrome. J. Hum. Genet. 2004, 49, 440-444. [CrossRef] [PubMed]

84. Kramer, J.M.; Kochinke, K.; Oortveld, M.A.; Marks, H.; Kramer, D.; de Jong, E.K.; Asztalos, Z.; Westwood, J.T.; Stunnenberg, H.G.; Sokolowski, M.B. Epigenetic regulation of learning and memory by Drosophila EHMT/G9a. PLoS Biol. 2011, 9, e1000569. [CrossRef] [PubMed]

85. Balemans, M.; Nadif Kasri, N.; Kopanitsa, M.V.; Afinowi, N.O.; Ramakers, G.; Peters, T.A.; Beynon, A.J.; Janssen, S.M.; van Summeren, R.C.; Eeftens, J.M. Hippocampal dysfunction in the Euchromatin histone methyltransferase 1 heterozygous knockout mouse model for Kleefstra syndrome. Hum. Mol. Genet. 2013, 22, 852-866. [CrossRef] [PubMed]

86. Martens, M.B.; Frega, M.; Classen, J.; Epping, L.; Bijvank, E.; Benevento, M.; van Bokhoven, H.; Tiesinga, P.; Schubert, D.; Kasri, N.N. Euchromatin histone methyltransferase 1 regulates cortical neuronal network development. Sci. Rep. 2016, 6, 35756. [CrossRef] [PubMed]

87. Benevento, M.; Iacono, G.; Selten, M.; Ba, W.; Oudakker, A.; Frega, M.; Keller, J.; Mancini, R.; Lewerissa, E.; Kleefstra, T. Histone methylation by the Kleefstra syndrome protein EHMT1 mediates homeostatic synaptic scaling. Neuron 2016, 91, 341-355. [CrossRef] [PubMed]

88. Kleefstra, T.; Kramer, J.M.; Neveling, K.; Willemsen, M.H.; Koemans, T.S.; Vissers, L.E.; Wissink-Lindhout, W.; Fenckova, M.; van den Akker, W.M.; Kasri, N.N. Disruption of an EHMT1-associated chromatin-modification module causes intellectual disability. Am. J. Hum. Genet. 2012, 91, 73-82. [CrossRef] [PubMed] 
89. Agha, Z.; Iqbal, Z.; Azam, M.; Ayub, H.; Vissers, L.E.; Gilissen, C.; Ali, S.H.B.; Riaz, M.; Veltman, J.A.; Pfundt, R. Exome sequencing identifies three novel candidate genes implicated in intellectual disability. PLoS ONE 2014, 9, e112687. [CrossRef] [PubMed]

90. Siderius, L.E.; Hamel, B.C.; van Bokhoven, H.; de Jager, F.; van den Helm, B.; Kremer, H.; Heineman-de Boer, J.A.; Ropers, H.H.; Mariman, E.C. X-linked mental retardation associated with cleft lip/palate maps to Xp11.3-q21.3. Am. J. Med. Genet. 1999, 85, 216-220. [CrossRef]

91. Laumonnier, F.; Holbert, S.; Ronce, N.; Faravelli, F.; Lenzner, S.; Schwartz, C.; Lespinasse, J.; Van Esch, H.; Lacombe, D.; Goizet, C. Mutations in PHF8 are associated with X linked mental retardation and cleft lip/cleft palate. J. Med. Genet. 2005, 42, 780-786. [CrossRef] [PubMed]

92. Abidi, F.; Miano, M.; Murray, J.; Schwartz, C. A novel mutation in the PHF8 gene is associated with X-linked mental retardation with cleft lip/cleft palate. Clin. Genet. 2007, 72, 19-22. [CrossRef] [PubMed]

93. Koivisto, A.; Ala-Mello, S.; Lemmelä, S.; Komu, H.; Rautio, J.; Järvelä, I. Screening of mutations in the PHF8 gene and identification of a novel mutation in a Finnish family with XLMR and cleft lip/cleft palate. Clin. Genet. 2007, 72, 145-149. [CrossRef] [PubMed]

94. Feng, W.; Yonezawa, M.; Ye, J.; Jenuwein, T.; Grummt, I. PHF8 activates transcription of rRNA genes through H3K4me3 binding and H3K9me1/2 demethylation. Nat. Struct. Mol. Biol. 2010, 17, 445-450. [CrossRef] [PubMed]

95. Kleine-Kohlbrecher, D.; Christensen, J.; Vandamme, J.; Abarrategui, I.; Bak, M.; Tommerup, N.; Shi, X.; Gozani, O.; Rappsilber, J.; Salcini, A.E. A functional link between the histone demethylase PHF8 and the transcription factor ZNF711 in X-linked mental retardation. Mol. Cell 2010, 38, 165-178. [CrossRef] [PubMed]

96. Qi, H.H.; Sarkissian, M.; Hu, G.-Q.; Wang, Z.; Bhattacharjee, A.; Gordon, D.B.; Gonzales, M.; Lan, F.; Ongusaha, P.P.; Huarte, M. Histone H4K20/H3K9 demethylase PHF8 regulates zebrafish brain and craniofacial development. Nature 2010, 466, 503-507. [CrossRef] [PubMed]

97. Riveiro, A.R.; Mariani, L.; Malmberg, E.; Amendola, P.G.; Peltonen, J.; Wong, G.; Salcini, A.E. JMJD-1.2/PHF8 controls axon guidance by regulating Hedgehog-like signaling. Development 2017, 144, 856-865. [CrossRef] [PubMed]

98. Walsh, R.M.; Shen, E.Y.; Bagot, R.C.; Anselmo, A.; Jiang, Y.; Javidfar, B.; Wojtkiewicz, G.J.; Cloutier, J.; Chen, J.W.; Sadreyev, R. Phf8 loss confers resistance to depression-like and anxiety-like behaviors in mice. Nat. Commun. 2017, 8, 15142. [CrossRef] [PubMed]

99. Weaver, D.D.; Graham, C.B.; Thomas, I.; Smith, D.W. A new overgrowth syndrome with accelerated skeletal maturation, unusual facies, and camptodactyly. J. Pediatr. 1974, 84, 547-552. [CrossRef]

100. Cohen, M.M. Mental deficiency, alterations in performance, and CNS abnormalities in overgrowth syndromes. Am. J. Med. Genet. 2003, 117C, 49-56. [CrossRef] [PubMed]

101. Tatton-Brown, K.; Murray, A.; Hanks, S.; Douglas, J.; Armstrong, R.; Banka, S.; Bird, L.M.; Clericuzio, C.L.; Cormier-Daire, V.; Cushing, T. Weaver syndrome and EZH2 mutations: Clarifying the clinical phenotype. Am. J. Med. Genet. 2013, 161, 2972-2980. [CrossRef] [PubMed]

102. Tatton-Brown, K.; Hanks, S.; Ruark, E.; Zachariou, A.; Duarte, S.D.V.; Ramsay, E.; Snape, K.; Murray, A.; Perdeaux, E.R.; Seal, S. Germline mutations in the oncogene EZH2 cause Weaver syndrome and increased human height. Oncotarget 2011, 2, 1127-1133. [CrossRef] [PubMed]

103. Gibson, W.T.; Hood, R.L.; Zhan, S.H.; Bulman, D.E.; Fejes, A.P.; Moore, R.; Mungall, A.J.; Eydoux, P.; Babul-Hirji, R.; An, J. Mutations in EZH2 cause Weaver syndrome. Am. J. Hum. Genet. 2012, 90, 110-118. [CrossRef] [PubMed]

104. Cao, R.; Wang, L.; Wang, H.; Xia, L.; Erdjument-Bromage, H.; Tempst, P.; Jones, R.S.; Zhang, Y. Role of histone H3 lysine 27 methylation in Polycomb-group silencing. Science 2002, 298, 1039-1043. [CrossRef] [PubMed]

105. Cohen, A.S.; Tuysuz, B.; Shen, Y.; Bhalla, S.K.; Jones, S.J.; Gibson, W.T. A novel mutation in EED associated with overgrowth. J. Hum. Genet. 2015, 60, 339-342. [CrossRef] [PubMed]

106. Pereira, J.D.; Sansom, S.N.; Smith, J.; Dobenecker, M.-W.; Tarakhovsky, A.; Livesey, F.J. Ezh2, the histone methyltransferase of PRC2, regulates the balance between self-renewal and differentiation in the cerebral cortex. Proc. Natl. Acad. Sci. USA 2010, 107, 15957-15962. [CrossRef] [PubMed]

107. Feng, X.; Juan, A.H.; Wang, H.A.; Ko, K.D.; Zare, H.; Sartorelli, V. Polycomb Ezh2 controls the fate of GABAergic neurons in the embryonic cerebellum. Development 2016, 143, 1971-1980. [CrossRef] [PubMed] 
108. Akizu, N.; García, M.A.; Estarás, C.; Fueyo, R.; Badosa, C.; de la Cruz, X.; Martínez-Balbás, M.A. EZH2 regulates neuroepithelium structure and neuroblast proliferation by repressing p21. Open Biol. 2016, 6, 150227. [CrossRef] [PubMed]

109. Zhang, J.; Ji, F.; Liu, Y.; Lei, X.; Li, H.; Ji, G.; Yuan, Z.; Jiao, J. Ezh2 regulates adult hippocampal neurogenesis and memory. J. Neurosci. 2014, 34, 5184-5199. [CrossRef] [PubMed]

110. Zhang, J.; Taylor, R.J.; La Torre, A.; Wilken, M.S.; Cox, K.E.; Reh, T.A.; Vetter, M.L. Ezh2 maintains retinal progenitor proliferation, transcriptional integrity, and the timing of late differentiation. Dev. Biol. 2015, 403, 128-138. [CrossRef] [PubMed]

111. Hirabayashi, Y.; Suzki, N.; Tsuboi, M.; Endo, T.A.; Toyoda, T.; Shinga, J.; Koseki, H.; Vidal, M.; Gotoh, Y. Polycomb limits the neurogenic competence of neural precursor cells to promote astrogenic fate transition. Neuron 2009, 63, 600-613. [CrossRef] [PubMed]

112. Yu, Y.-L.; Chou, R.-H.; Chen, L.-T.; Shyu, W.-C.; Hsieh, S.-C.; Wu, C.-S.; Zeng, H.-J.; Yeh, S.-P.; Yang, D.-M.; Hung, S.-C. EZH2 regulates neuronal differentiation of mesenchymal stem cells through PIP5K1C-dependent calcium signaling. J. Biol. Chem. 2011, 286, 9657-9667. [CrossRef] [PubMed]

113. Hwang, W.W.; Salinas, R.D.; Siu, J.J.; Kelley, K.W.; Delgado, R.N.; Paredes, M.F.; Alvarez-Buylla, A.; Oldham, M.C.; Lim, D.A. Distinct and separable roles for EZH2 in neurogenic astroglia. Elife 2014, 3, e02439. [CrossRef] [PubMed]

114. Di Meglio, T.; Kratochwil, C.F.; Vilain, N.; Loche, A.; Vitobello, A.; Yonehara, K.; Hrycaj, S.M.; Roska, B.; Peters, A.H.; Eichmann, A. Ezh2 orchestrates topographic migration and connectivity of mouse precerebellar neurons. Science 2013, 339, 204-207. [CrossRef] [PubMed]

115. Zhao, Q.; Rank, G.; Tan, Y.T.; Li, H.; Moritz, R.L.; Simpson, R.J.; Cerruti, L.; Curtis, D.J.; Patel, D.J.; Allis, C.D. PRMT5-mediated methylation of histone H4R3 recruits DNMT3A, coupling histone and DNA methylation in gene silencing. Nat. Struct. Mol. Biol. 2009, 16, 304-311. [CrossRef] [PubMed]

116. Tien, C.-L.; Jones, A.; Wang, H.; Gerigk, M.; Nozell, S.; Chang, C. Snail2/Slug cooperates with Polycomb repressive complex 2 (PRC2) to regulate neural crest development. Development 2015, 142, 722-731. [CrossRef] [PubMed]

117. Kurotaki, N.; Imaizumi, K.; Harada, N.; Masuno, M.; Kondoh, T.; Nagai, T.; Ohashi, H.; Naritomi, K.; Tsukahara, M.; Makita, Y. Haploinsufficiency of NSD1 causes Sotos syndrome. Nat. Genet. 2002, 30, 365-366. [CrossRef] [PubMed]

118. Sotos, J.F.; Dodge, P.R.; Muirhead, D.; Crawford, J.D.; Talbot, N.B. Cerebral gigantism in childhood: A syndrome of excessively rapid growth with acromegalic features and a nonprogressive neurologic disorder. N. Engl. J. Med. 1964, 271, 109-116. [CrossRef] [PubMed]

119. Žilina, O.; Reimand, T.; Tammur, P.; Tillmann, V.; Kurg, A.; Õunap, K. Patient with dup (5) (q35.2-q35.3) reciprocal to the common Sotos syndrome deletion and review of the literature. Eur. J. Med. Genet. 2013, 56, 202-206. [CrossRef] [PubMed]

120. Berdasco, M.; Ropero, S.; Setien, F.; Fraga, M.F.; Lapunzina, P.; Losson, R.; Alaminos, M.; Cheung, N.-K.; Rahman, N.; Esteller, M. Epigenetic inactivation of the Sotos overgrowth syndrome gene histone methyltransferase NSD1 in human neuroblastoma and glioma. Proc. Natl. Acad. Sci. USA 2009, 106, 21830-21835. [CrossRef] [PubMed]

121. Visser, R.; Landman, E.B.; Goeman, J.; Wit, J.M.; Karperien, M. Sotos syndrome is associated with deregulation of the MAPK/ERK-signaling pathway. PLoS ONE 2012, 7, e49229. [CrossRef] [PubMed]

122. Malan, V.; Rajan, D.; Thomas, S.; Shaw, A.C.; Louis Dit Picard, H.; Layet, V.; Till, M.; van Haeringen, A.; Mortier, G.; Nampoothiri, S.; et al. Distinct effects of allelic NFIX mutations on nonsense-mediated mRNA decay engender either a Sotos-like or a Marshall-Smith syndrome. Am. J. Hum. Genet. 2010, 87, 189-198. [CrossRef] [PubMed]

123. Almuriekhi, M.; Shintani, T.; Fahiminiya, S.; Fujikawa, A.; Kuboyama, K.; Takeuchi, Y.; Nawaz, Z.; Nadaf, J.; Kamel, H.; Kitam, A.K. Loss-of-function mutation in APC2 causes Sotos syndrome features. Cell Rep. 2015, 10, 1585-1598. [CrossRef] [PubMed]

124. Engström, W.; Lindham, S.; Schofield, P. Wiedemann-Beckwith syndrome. Eur. J. Pediatr. 1988, 147, $450-457$. [CrossRef] [PubMed]

125. Martínez-y-Martínez, R.; Martínez-Carboney, R.; Ocampo-Campos, R.; Rivera, H.; Cuevas, A.; Martín, M.M. Wiedemann-Beckwith syndrome: Clinical, cytogenetical and radiological observations in 39 new cases. Genet. Couns. 1992, 3, 67-76. [PubMed] 
126. Waziri, M.; Patil, S.R.; Hanson, J.W.; Bartley, J.A. Abnormality of chromosome 11 in patients with features of Beckwith-Wiedemann syndrome. J. Pediatr. 1983, 102, 873-876. [CrossRef]

127. Baujat, G.; Rio, M.; Rossignol, S.; Sanlaville, D.; Lyonnet, S.; Le Merrer, M.; Munnich, A.; Gicquel, C.; Cormier-Daire, V.; Colleaux, L. Paradoxical NSD1 mutations in Beckwith-Wiedemann syndrome and 11p15 anomalies in Sotos syndrome. Am. J. Hum. Genet. 2004, 74, 715-720. [CrossRef] [PubMed]

128. Battaglia, A.; Carey, J.C.; Cederholm, P.; Viskochil, D.H.; Brothman, A.R.; Galasso, C. Natural history of Wolf-Hirschhorn syndrome: Experience with 15 cases. Pediatrics 1999, 103, 830-836. [CrossRef] [PubMed]

129. Näf, D.; Wilson, L.A.; Bergstrom, R.A.; Smith, R.S.; Goodwin, N.C.; Verkerk, A.; van Ommen, G.J.; Ackerman, S.L.; Frankel, W.N.; Schimenti, J.C. Mouse models for the Wolf-Hirschhorn deletion syndrome. Hum. Mol. Genet. 2001, 10, 91-98. [CrossRef] [PubMed]

130. Lee, Y.F.; Nimura, K.; Lo, W.N.; Saga, K.; Kaneda, Y. Histone H3 lysine 36 methyltransferase Whsc1 promotes the association of RUNX2 and p300 in the activation of bone-related genes. PLoS ONE 2014, 9, e106661. [CrossRef] [PubMed]

131. Bicknell, L.S.; Walker, S.; Klingseisen, A.; Stiff, T.; Leitch, A.; Kerzendorfer, C.; Martin, C.-A.; Yeyati, P.; Al Sanna, N.; Bober, M. Mutations in ORC1, encoding the largest subunit of the origin recognition complex, cause microcephalic primordial dwarfism resembling Meier-Gorlin syndrome. Nat. Genet. 2011, 43, 350-355. [CrossRef] [PubMed]

132. Shalev, S.A.; Hall, J.G. Another adult with Meier-Gorlin syndrome-insights into the natural history. Clin. Dysmorphol. 2003, 12, 167-169. [CrossRef] [PubMed]

133. Bicknell, L.S.; Bongers, E.M.; Leitch, A.; Brown, S.; Schoots, J.; Harley, M.E.; Aftimos, S.; Al-Aama, J.Y.; Bober, M.; Brown, P.A. Mutations in the pre-replication complex cause Meier-Gorlin syndrome. Nat. Genet. 2011, 43, 356-359. [CrossRef] [PubMed]

134. Peter, C.J.; Akbarian, S. Balancing histone methylation activities in psychiatric disorders. Trends Mol. Med. 2011, 17, 372-379. [CrossRef] [PubMed]

135. Copeland, R.A.; Solomon, M.E.; Richon, V.M. Protein methyltransferases as a target class for drug discovery. Nat. Rev. Drug Discov. 2009, 8, 724-732. [CrossRef] [PubMed]

136. Liu, Y.; Liu, K.; Qin, S.; Xu, C.; Min, J. Epigenetic targets and drug discovery: Part 1: Histone methylation. Pharmacol. Ther. 2014, 143, 275-294. [CrossRef] [PubMed]

137. Knutson, S.K.; Wigle, T.J.; Warholic, N.M.; Sneeringer, C.J.; Allain, C.J.; Klaus, C.R.; Sacks, J.D.; Raimondi, A.; Majer, C.R.; Song, J. A selective inhibitor of EZH2 blocks H3K27 methylation and kills mutant lymphoma cells. Nat. Chem. Biol. 2012, 8, 890-896. [CrossRef] [PubMed]

138. McCabe, M.T.; Ott, H.M.; Ganji, G.; Korenchuk, S.; Thompson, C.; Van Aller, G.S.; Liu, Y.; Graves, A.P.; Diaz, E.; LaFrance, L.V. EZH2 inhibition as a therapeutic strategy for lymphoma with EZH2-activating mutations. Nature 2012, 492, 108-112. [CrossRef] [PubMed]

139. Qi, W.; Chan, H.; Teng, L.; Li, L.; Chuai, S.; Zhang, R.; Zeng, J.; Li, M.; Fan, H.; Lin, Y. Selective inhibition of Ezh2 by a small molecule inhibitor blocks tumor cells proliferation. Proc. Natl. Acad. Sci. USA 2012, 109, 21360-21365. [CrossRef] [PubMed]

140. Kim, D.H.; Sætrom, P.; Snøve, O.; Rossi, J.J. MicroRNA-directed transcriptional gene silencing in mammalian cells. Proc. Natl. Acad. Sci. USA 2008, 105, 16230-16235. [CrossRef] [PubMed]

141. Varambally, S.; Cao, Q.; Mani, R.-S.; Shankar, S.; Wang, X.; Ateeq, B.; Laxman, B.; Cao, X.; Jing, X.; Ramnarayanan, K. Genomic loss of microRNA-101 leads to overexpression of histone methyltransferase EZH2 in cancer. Science 2008, 322, 1695-1699. [CrossRef] [PubMed]

142. Hawkins, P.G.; Santoso, S.; Adams, C.; Anest, V.; Morris, K.V. Promoter targeted small RNAs induce long-term transcriptional gene silencing in human cells. Nucleic Acids Res. 2009, 37, 2984-2995. [CrossRef] [PubMed]

(C) 2017 by the authors. Licensee MDPI, Basel, Switzerland. This article is an open access article distributed under the terms and conditions of the Creative Commons Attribution (CC BY) license (http:/ / creativecommons.org/licenses/by/4.0/). 